\title{
The Innovation of Purple Sweet Potato Noodle Processing (Test of Sensory Quality Analysis)
}

\section{Mahdiyah}

Food and Nutrition Study Program, State University of Jakarta, Jakarta, Indonesia

\section{Abstract}

The purple sweet potatoes as local food ingredients can be used optimally for national food availability by improving the quality of purple sweet potato noodle products using the right formulations is the goal of this study. The purple sweet potato noodles were tested through sensory quality by expert panelists including color, taste, flavor, and elasticity. The substitution of wheat flour with 30,40 , and $50 \%$ of purple sweet potatoes is still considered good quality for purple sweet potato noodles. Hypothesis test results using the Kruskal-Wallis test at a significance level of $\alpha 0.05$ proved that

Corresponding Author: Mahdiyah

mahdiyah@unj.ac.id

Received: 11 January 2019

Accepted: 14 February 2019

Published: 25 March 2019

Publishing services provided by Knowledge E

(c) Mahdiyah. This article is distributed under the terms of the Creative Commons

Attribution License, which permits unrestricted use and redistribution provided that the original author and source are credited.

Selection and Peer-review under the responsibility of the 3rd ICTVET 2018 Conference Committee. purple sweet potato noodle with a $40 \%$ substitution was the best formulation. The implication of processing purple sweet potato noodles is to reduce the dependence on imported food ingredients such as wheat flour because it is expected that some of the food ingredients used can be replaced by local food sources such as purple sweet potatoes.

Keywords: noodles, purple sweet potato, sensory quality

\section{Introduction}

Most of the Indonesian people consume noodles as an alternative staple food other than rice. Indonesia is listed as the third country in the largest number of noodle consuming in the world, with 14 billion packs per year. The main ingredients in making noodles are wheat flour, water, salt, eggs, and alkaline salt [1].

The process of noodle processing is done by stages: Mixing, resting the dough, pressing the mixture, resting the dough sheet, thinning the dough sheet, cutting into strands of noodles, and boiling. In principle, noodles are classified as raw Chinese noodle, wet noodles (boiled noodle), steam, and dried noodle, and instant noodles $[1,2]$.

Purple sweet potato noodle processing aims to enrich the innovation of noodles using local food ingredients, improve taste, reduce dependence on wheat imports, and 
better nutritional value with the advantages of fiber content, complex carbohydrates, protein, vitamin A, vitamin C, iron, and calcium $[3,4]$. This innovation also follows the trend of tastes or preferences of the community, especially adolescents for various types of foods that are interesting, unique and always with changes such as sweet purple noodles without the color additive.

One important step in the processing of wet noodles is boiling, which is the process of starch gelatinization and gluten coagulation with dehydration of water which will cause noodles and elasticity to become hard and strong [1, 2].
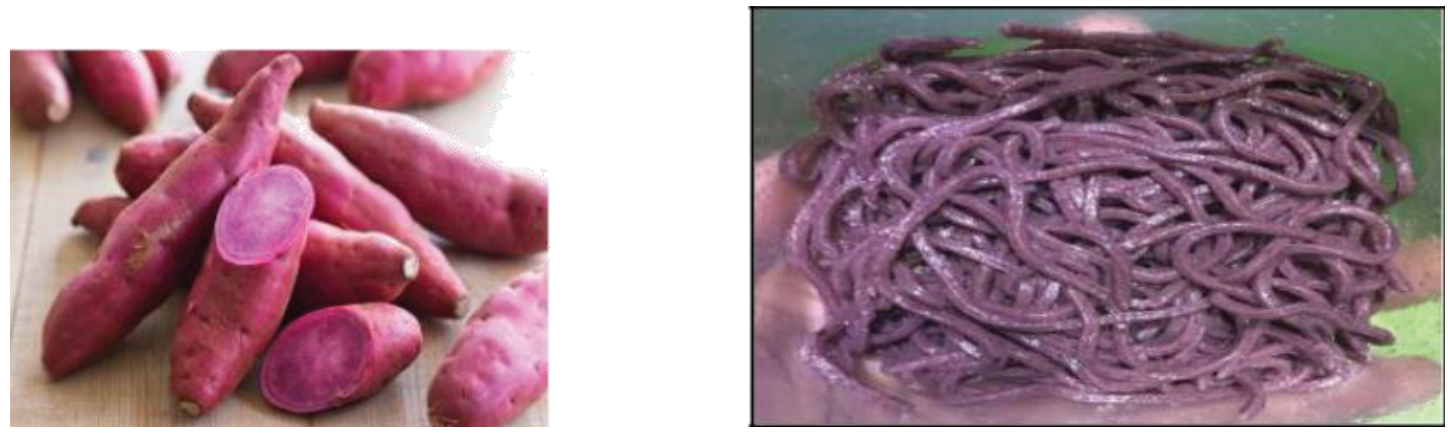

Figure 1: Purple Sweet Potato Bulbs and Noodles.

Nutrient content of noodles depends on the type, amount, and quality of the constituent ingredients, as well as the way they are made and stored. The nutritional content of wet noodles (100 grams of ingredients) can be seen in the following table:

TABLE 1: Nutritional Content of Noodles.

\begin{tabular}{l|c|c|}
\hline Nutrient Content & Wet Noodle & Dry Noodle \\
\hline Energy (Kal) & 86,0 & 337,0 \\
\hline Protein (g) & 0,6 & 7,9 \\
\hline Fat (g) & 3,3 & 11,8 \\
\hline Carbohydrate (g) & 14,0 & 50,0 \\
\hline Calcium (mg) & 14,0 & 49,0 \\
\hline Phosphor (mg) & 13,0 & 47,0 \\
\hline Iron (mg) & 0,8 & 2,8 \\
\hline Water (gr) & 80,0 & 28,6 \\
\hline Source: Departemen Kesehatan Republik Indonesia (2009) [5].
\end{tabular}

\section{Methods}

This study uses an experimental method with the addition of purple sweet potatoes into noodle dough as much as 30\%, 40\%, and 50\%. Furthermore, to assess wet noodles, it is carried out by sensory quality tests including aspects of color, taste, flavor, and elasticity. 
Research variables are attributes or characteristics of objects that have certain variations determined by researchers from a case $[6,7]$. The independent variable in this study is the addition of purple sweet potatoes that are $30 \%, 40 \%, 50 \%$. The dependent variable of this study was the sensory quality value of purple sweet potato noodles.

The assessment of the quality of the three best formulas of purple sweet potato noodles was tested on each of 30 trained panelists. Determination of the quality test results on sensory quality noodles used a five-level Likert scale. Hypothesis testing is done using the Kruskal Wallis Test, followed by the Tuckey's Test [6] to find out the most qualified formulations including aspects of Color, Taste, Flavor,

$$
K \frac{12}{n(n+1)}\left(\sum_{j=1}^{c} \frac{T_{3}^{2}}{n j}\right)-3(n+1)
$$

and Elasticity. Kruskal Wallis Formula:

Tukey's Test Formula:

$$
Q=\frac{X^{i}-X^{j}}{\sqrt{\frac{\text { Rata-rata JK dalam kelompok }}{n}}}
$$

\section{Results}

\subsection{Color}

The results of the analysis of panelists' assessment of the color aspects of purple sweet potato noodles with a percentage of 30, 40 and 50 with a 5-level Likert scale, sequentially from the best to bad color quality namely dark purple, purple, light purple, brownish brown and brown.

The results of the hypothesis test analysis of the color aspects of purple sweet potato wet noodles can be seen as follows:

TABLE 2: Kruskal-Wallis Analysis of the Color Aspect of Purple Sweet Wet Noodles.

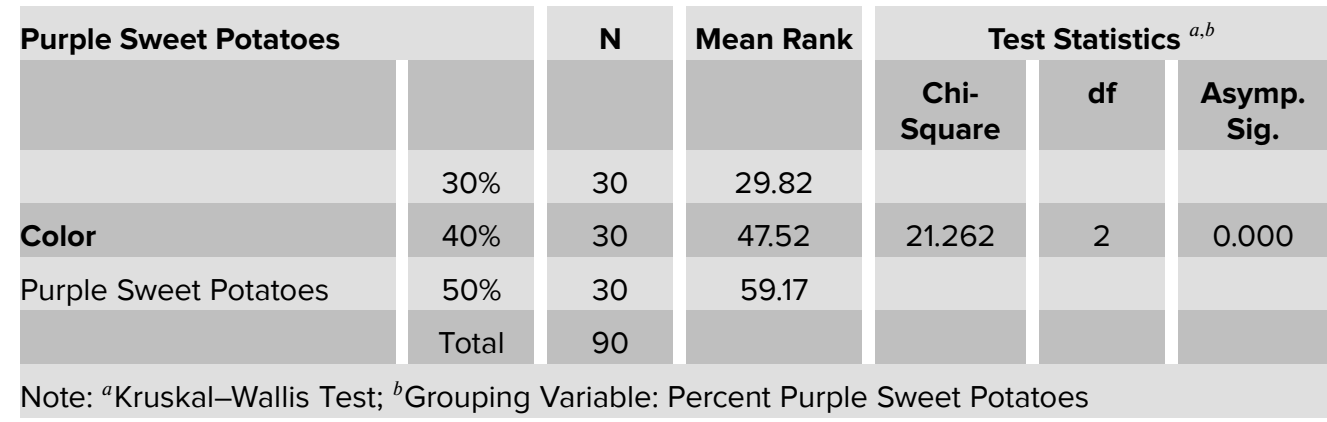


The mean rank value of the highest color of purple sweet potato noodles in a sequence is $50 \%, 40 \%$ and $30 \%$ substitution of purple sweet potato with a value of 59.17; 47.52 and 29.82 .

The results of the Kruskal Wallis hypothesis test show that there are significant differences in the color of wet noodles based on the percentage of $30 \%, 40 \%$ and $50 \%$ purple sweet potato flour (Asymp. Sig. $=0.000$ ). Furthermore the results of the Tukey test show:

TABLE 3: Tukey Analysis of the Color Aspect of Purple Sweet Wet Noodles.

\begin{tabular}{|c|c|c|c|}
\hline \multicolumn{4}{|c|}{ Color Purple Sweet Potatoes } \\
\hline \multicolumn{4}{|c|}{ Tukey HSD ${ }^{a, b}$} \\
\hline \multicolumn{2}{|l|}{ Percent } & \multicolumn{2}{|c|}{ Subset } \\
\hline Purple Sweet Potatoes & $\mathrm{N}$ & 1 & 2 \\
\hline $30 \%$ & 30 & 3.37 & \\
\hline $40 \%$ & 30 & & 3.97 \\
\hline $50 \%$ & 30 & & 4.27 \\
\hline Sig. & & 1.000 & 0.345 \\
\hline
\end{tabular}

Tukey test results showed that there were significant differences in the color of wet noodles between $40 \%$ and $50 \%$ substitution of $30 \%$ purple sweet potato substitution respectively. While between $40 \%$ and $50 \%$ substitution there is no difference. These results are reinforced by a subset or grouping table, namely $30 \%$ substitution in different groups with a substitution of $40 \%$ and $50 \%$ purple sweet potato flour. This means that the analysis proves that the color of purple sweet potato noodles is better with a substitution of $40 \%$ and $50 \%$ purple sweet potato flour compared with a $30 \%$ substitution.

\subsection{Taste}

Based on the scoring score with a 5-level Likert scale, sequentially from the best to the bad taste quality, which is somewhat purple sweet potato, purple sweet potato flavor, purple sweet potato flavor, purple sweet potato flavor, and purple sweet potato flavor. The results of the evaluation of trained panelists, for treatment $30 \%, 40 \%$ and $50 \%$ purple sweet potato and then can be proved by the analysis of the hypothesis as follows:

The highest mean rank of wet noodle taste in the sequence is at $30 \%, 40 \%$ and $50 \%$ substitution of purple sweet potato flour with a value of $64.57 ; 48.83$ and 23.10 . Furthermore the results of the Tukey differentiation test show: 
TABLE 4: Kruskal-Wallis Analysis of the Taste Aspect of Purple Sweet Wet Noodles.

\begin{tabular}{|c|c|c|c|c|c|c|}
\hline \multirow[t]{2}{*}{ Percent } & \multirow{2}{*}{$\begin{array}{c}\text { Purple Sweet } \\
\text { Potatoes }\end{array}$} & \multirow[t]{2}{*}{$\mathrm{N}$} & \multirow{2}{*}{$\begin{array}{l}\text { Mean } \\
\text { Rank }\end{array}$} & \multicolumn{3}{|c|}{ Test Statistics ${ }^{a, b}$} \\
\hline & & & & $\begin{array}{l}\text { Chi- } \\
\text { Square }\end{array}$ & $\mathrm{df}$ & $\begin{array}{c}\text { Asymp. } \\
\text { Sig. }\end{array}$ \\
\hline & $30 \%$ & 30 & 64.57 & & & \\
\hline Taste & $40 \%$ & 30 & 48.83 & 42.795 & 2 & 0.000 \\
\hline \multirow[t]{2}{*}{ Purple Sweet Potatoes } & $50 \%$ & 30 & 23.10 & & & \\
\hline & Total & 90 & & & & \\
\hline
\end{tabular}

TABLE 5: Tukey Analysis of the Taste Aspect of Purple Sweet Wet Noodles.

\begin{tabular}{|c|c|c|c|c|}
\hline \multicolumn{5}{|c|}{ Taste Purple Sweet Potatoes } \\
\hline \multicolumn{5}{|l|}{ Tukey HSD ${ }^{a, b}$} \\
\hline \multicolumn{2}{|l|}{ Percent } & \multicolumn{3}{|c|}{ Subset } \\
\hline Purple Sweet Potatoes & $\mathrm{N}$ & 1 & 2 & 3 \\
\hline $50 \%$ & 30 & 2.57 & & \\
\hline $40 \%$ & 30 & & 4.03 & \\
\hline $30 \%$ & 30 & & & 4.57 \\
\hline Sig. & & 1.000 & 1.000 & 1.000 \\
\hline
\end{tabular}

Note: Means for groups in homogeneous subsets are displayed; ${ }^{a}$ Alpha $=0.05$.

Tukey analysis shows that there is a significant difference in noodle taste between each formulation. This result is reinforced by a table of subsets that classify each formulation of $30 \%, 40 \%$ and $50 \%$ purple sweet potato noodles in different groups. This means that the results of the analysis prove that the taste of purple sweet potato noodles is better with $30 \%, 40 \%$ and $50 \%$ purple sweet potato substitution.

\subsection{Flavor}

The flavor of purple sweet potato noodles is rated at 5-level Likert, sequentially from the score of the best to bad flavor quality, which is somewhat sweet purple, sweet purple, not purple sweet potato, very purple and very sweet purple sweet potato. The results of the analysis of hypothesis testing aspects of the flavor of purple sweet potato wet noodles can be seen as follows:

The mean rank of the highest flavor of wet noodles in the sequence is at $30 \%, 40 \%$ and $50 \%$ substitution of purple sweet potato flour with values of $66.73,44.43$ and 25.33 . Furthermore the results of the Tukey test show: 
TABLE 6: Kruskal-Wallis Analysis of the Flavor Aspect of Purple Sweet Wet Noodles.

\begin{tabular}{l|c|c|c|c|c|c|}
\hline Percent & $\begin{array}{c}\text { Purple Sweet } \\
\text { Potatoes }\end{array}$ & N & $\begin{array}{c}\text { Mean } \\
\text { Rank }\end{array}$ & \multicolumn{2}{|c|}{ Test Statistics } \\
\hline & & & $\begin{array}{c}\text { Chi- } \\
\text { Square }\end{array}$ & df & $\begin{array}{c}\text { Asymp. } \\
\text { Sig. }\end{array}$ \\
\hline Flavor & $30 \%$ & 30 & 66.73 & & & \\
\hline Purple Sweet Potatoes & $40 \%$ & 30 & 44.43 & 42.678 & 2 & 0.000 \\
\hline Noodles & $50 \%$ & 30 & 25.33 & & & \\
\hline Total & & 90 & & & \\
\hline Note: ${ }^{a}$ Kruskal-Wallis Test; ${ }^{b}$ Grouping Variable: Percentage Ubi Ungu.
\end{tabular}

TABLE 7: Tukey Analysis of the Flavor Aspect of Purple Sweet Wet Noodles.

\begin{tabular}{|c|c|c|c|c|}
\hline \multicolumn{5}{|c|}{ Flavor Purple Sweet Potatoes Noodles } \\
\hline \multicolumn{5}{|l|}{ Tukey HSD ${ }^{a, b}$} \\
\hline \multicolumn{2}{|l|}{ Percent } & \multicolumn{3}{|c|}{ Subset } \\
\hline Purple Sweet Potatoes & $\mathrm{N}$ & 1 & 2 & 3 \\
\hline \multicolumn{5}{|l|}{ Noodles } \\
\hline $50 \%$ & 30 & 2.73 & & \\
\hline $40 \%$ & 30 & & 3.80 & \\
\hline $30 \%$ & 30 & & & 4.60 \\
\hline Sig. & & 1.000 & 1.000 & 1.000 \\
\hline
\end{tabular}

Tukey test results showed that there were significant differences in noodle flavor between the formulations of purple sweet potato $30 \%, 40 \%$, and $50 \%$, with a table of subset found in different groups.

This means that the results of the analysis prove that the flavor of purple sweet potato noodles is better sequentially is wet noodles with a substitution of $30 \%$ and $40 \%$ and $50 \%$.

\subsection{Elasticity}

Based on the scoring score with a 5-level Likert scale, sequentially from the best to the bad elasticity is chewy, slightly springy, very chewy, not springy and not very elastic. The results of an assessment by panelists were somewhat trained, for formulations of $30 \%, 40 \%$, and $50 \%$ purple sweet potato and could then be proved by analysis of the hypothesis using the Kruskal-Wallis test. The results of the hypothesis test analysis of the elasticity of purple sweet potato noodles can be seen as follows: 
TABLE 8: Kruskal-Wallis Analysis of the Elasticity Aspect of Purple Sweet Wet Noodles.

\begin{tabular}{l|l|l|l|l|l|l|}
\hline & $\begin{array}{c}\text { Purple Sweet } \\
\text { Potatoes }\end{array}$ & N & $\begin{array}{c}\text { Mean } \\
\text { Rank }\end{array}$ & \multicolumn{2}{|c|}{ Test Statistics ${ }^{a, b}$} \\
\hline & & & & $\begin{array}{c}\text { Chi- } \\
\text { Square }\end{array}$ & df & $\begin{array}{c}\text { Asymp. } \\
\text { Sig. }\end{array}$ \\
\hline Elasticity & $30 \%$ & 30 & 43.90 & & \\
\hline
\end{tabular}

The results of the Kruskal-Wallis hypothesis test showed that there were significant differences in the elasticity of wet noodles based on the percentage of $30 \%, 40 \%$ and $50 \%$ purple sweet potato flour (Asymp. Sig. $=0.007$ ). The highest purple sweet potato noodle formula with the highest elasticity quality is $40 \%, 30 \%$ and $50 \%$ purple sweet potato with values of $56.17,43.90$ and 36.43 .

Tuckey's differentiation test is then performed to determine the formula that has the best elasticity, as follows:

TABLE 9: Tukey Analysis of the Elasticity Aspect of Purple Sweet Wet Noodles.

\begin{tabular}{|c|c|c|c|}
\hline \multicolumn{4}{|l|}{ Tukey HSD ${ }^{a, b}$} \\
\hline \multirow{2}{*}{$\begin{array}{l}\text { Percent } \\
\text { Purple Sweet Potatoes }\end{array}$} & \multirow[b]{2}{*}{$\mathbf{N}$} & \multicolumn{2}{|c|}{ Subset } \\
\hline & & 1 & 2 \\
\hline $50 \%$ & 30 & 3.77 & \\
\hline $30 \%$ & 30 & 4.07 & 4.07 \\
\hline $40 \%$ & 30 & & 4.53 \\
\hline Sig. & & 0.384 & 0.103 \\
\hline
\end{tabular}

Tukey test results showed that there were significant differences in the texture of wet noodles between each $40 \%$ substitution of $50 \%$ purple sweet potato substitution. While between $30 \%$ substitution and $50 \%$ purple sweet potato on wet noodles, there was no difference. These results are reinforced by a subset or grouping table, which is a formulation of $30 \%$ and $50 \%$ found in different groups with $30 \%$ and $40 \%$ purple sweet potato noodles. 


\section{Discussion}

The results of the Kruskal Wallis hypothesis test showed that there were significant differences in the color of wet noodles based on $30 \%, 40 \%$, and $50 \%$ substitution rates for purple sweet potato flour (Asymp. Sig. $=0.000$ ). These results are reinforced by a subset or grouping table, namely $30 \%$ substitution in different groups with a substitution of $40 \%$ and $50 \%$ purple sweet potato flour. The results of this analysis prove that the color of purple sweet potato noodles is better with a substitution of $40 \%$ and $50 \%$ purple sweet potato flour compared with a $30 \%$ substitution. The red and purple contents of purple sweet potato are anthocyanins compounds. The form of anthocyanin which is mostly contained in purple sweet potatoes is a form of cyanide and peonidin which are mostly in acylated form. The realized anthocyanins are relatively more stable when compared to non-acylated anthocyanins. This is what produces anthocyanins from purple sweet potatoes with great potential as a source of natural dyes.

The results of the Kruskal-Wallis hypothesis test showed that there were significant differences in wet noodle taste based on $30 \%, 40 \%$, and $50 \%$ purple sweet potato substitution percentage (Asymp. Sig. $=0.000)$. The Tukey test shows that there is a significant difference in noodle flavor between each formulation. This result is reinforced by a table of subsets that classify each formulation of $30 \%, 40 \%$, and $50 \%$ purple sweet potato noodles in different groups. This means that the analysis proves that the taste of purple sweet potato noodles is better in the formula $30 \%, 40 \%$, and $50 \%$ purple sweet potato. This difference in taste is because sweet potatoes contain several types of sugars such as oligosaccharides.

The results of the analysis on the flavor aspect of purple sweet potato noodles are reinforced by a subset or grouping table, namely $30 \%$ formulation in different groups with $40 \%$ and $50 \%$ purple sweet potato. This analysis shows that the flavor in purple sweet potatoes affects the flavor of noodle products produced. Sequentially the quality of the flavor of noodles is at the formula $30 \%, 40 \%$ and last $50 \%$.

The test results showed that there was an effect of different formulas on the elasticity of purple sweet potato noodles. The highest purple sweet potato noodle formula with the highest elasticity quality is $40 \%, 30 \%$ and $50 \%$ purple sweet potato with values of 56.17, 43.90 and 36.43. However, Tukey's analysis proved that the elasticity of purple sweet potato noodles was better in the $40 \%$ formula compared to the $30 \%$ formula and $50 \%$ purple sweet potato. 
In general, based on the results of sensory quality testing of the four aspects of color, taste, flavor and elasticity, the product that has the best quality by consumer assessment is a formula with a percentage of $40 \%$ purple sweet potato.

\section{Conclusion}

The results of the study proved that the addition of purple sweet potato to the noodle formula was considered to have met the quality standards through sensory quality testing. Of the three types of formulas studied, namely $30 \%, 40 \%$ and $50 \%$, the results of hypothesis testing using the Tuckey test at a significant level $\alpha 0.05$, it is known that there is a significant effect of adding purple sweet potatoes to the noodles including aspects of color, taste, flavor, and elasticity. In general, based on the results of the sensory quality test using the Tukey multiplier test, showed that noodles with $40 \%$ purple sweet potato addition were the most quality products based on consumer assessment using sensory quality analysis. The results of this study show positive contributions to support government programs in optimizing the use of local purple sweet potato food ingredients.

\section{Acknowledgment}

The authors would like to thank their colleague and students for their contribution and support to the research. They are also thankful to all the reviewers who gave their valuable inputs to the manuscript and helped in completing the paper.

\section{References}

[1] Hou, G. G. (2012). Asian Noodles Science, Technology, and Processing. New Jersey: A John Wiley \& Sons, Inc., Publication.

[2] Astawan, I Made. (2008). Membuat Mi dan Bihun. Depok. Penebar Swadaya.

[3] Richana, Nur. (2013). Menggali Potensi Ubi Kayu dan Ubi Jalar. Bandung: Nuansa Cendekia.

[4] Standarisasi Nasional (BSN). (2015). Mie Basah. SNI 2987-2015.

[5] Departemen Kesehatan Republik Indonesia. (2009). Tabel Komposisi Bahan Makanan. Jakarta: PT. Elex Media Komputindo.

[6] Sheskin, D.J. (2012). Handbook of Parametric and Nonparametric Statistical Procedures, Fifth Edition. Florida: Chapman and Hall/CRC. 
[7] Mahdiyah. (2014). Statistik Pendidikan. Bandung: PT. Remaja Rosdakarya. 